\title{
Congenital peritoneopericardial diaphragmatic hernia in a geriatric Persian cat
}

\author{
[Hérnia diafragmática peritoneopericárdica congênita em gato Persa geriátrico]
}

\section{"Case Report/Relato de Caso"}

\author{
Anderson Barros Archanjo ${ }^{1}$, Marcel Arcanjo Silva Azevedo ${ }^{2}$, Dyeime Ribeiro Souza ${ }^{2}$, Leonardo \\ Oliveira Trivilin ${ }^{2,3}$, Paulo Sérgio Cruz Andrade Júnior ${ }^{3}$, Camila Barbosa Amaral ${ }^{3}$, Louisiane \\ Carvalho Nunes ${ }^{2,3 *}$
}

${ }^{1}$ Programa de Pós-Graduação em Biotecnologia, Universidade Federal do Espírito Santo, Vitória-ES, Brasil.
2Programa de Pós-Graduação em Ciências Veterinárias, Universidade Federal do Espírito Santo, Alegre-ES, Brasil.
${ }^{3}$ Departamento de Medicina Veterinária, Universidade Federal do Espírito Santo, Alegre-ES, Brasil.
*Autor para correspondência/Corresponding author: E-mail: louisianecn@ gmail.com

\begin{abstract}
Peritoneopericardial diaphragmatic hernia (PPDH) is a rare condition that is caused by defective diaphragm and pericardium development. It occurs in dogs and cats and is most prevalent in Weimaraner and Persian breeds. This study presents the first report of a congenital peritoneopericardial diaphragmatic hernia in a geriatric cat in Espírito Santo in Brazil. A 12-year old male Persian cat was referred to the veterinary hospital. Clinical examination revealed hyporexia, cachexia, alopecia, dyspnea, and an adherent and irregularly shaped nodule in the left caudal breast. Cytopathological examination of the abdominal nodulation revealed a mammary carcinoma. Thoracic radiography revealed PPDH. The animal was euthanized. On necropsy, the abdominal cavity revealed a part of the liver inside the diaphragm, and the thoracic view revealed the heart and liver inside the pericardial sac. Histopathological analysis confirmed mammary carcinoma and revealed dermatophytic pseudomycetoma. This is the first report of PPDH, which was incidentally detected, in a geriatric Persian cat that had survived for several years without diagnosis in Espírito Santo, Brazil. From the observations made, we conclude that comprehensive clinical examination, involving imaging, is important in detecting congenital abnormalities such as PPDH.
\end{abstract}

Keywords: feline; PPDH; congenital defect; imaging diagnosis; necropsy.

\section{Resumo}

A hérnia diafragmática peritoneopericárdica (PPDH) é uma condição rara causada pelo desenvolvimento defeituoso do diafragma e pericárdio. Ocorre em cães e gatos, sendo mais prevalente nas raças Weimaraner e Persa. Este estudo apresenta o primeiro relato de hérnia diafragmática peritoneopericárdica congênita em um gato geriátrico no Espírito Santo no Brasil. Um gato persa macho de 12 anos foi encaminhado ao Hospital Veterinário. O exame clínico revelou hiporexia, caquexia, alopecia, dispneia e nódulo aderente e de formato irregular na mama caudal esquerda. $\mathrm{O}$ exame citopatológico da nodulação abdominal revelou carcinoma mamário. A radiografia torácica revelou PPDH. O animal foi sacrificado. Na necropsia, a cavidade abdominal revelou parte do fígado dentro do diafragma e a visão torácica revelou o coração e o fígado dentro do saco pericárdico. A análise histopatológica confirmou carcinoma mamário e revelou pseudomicetoma dermatofítico. Este é o primeiro relato de PPDH, detectado incidentalmente, em um gato persa geriátrico que sobreviveu por vários anos sem diagnóstico no Espírito Santo, Brasil. A partir das observações feitas, concluímos que um exame clínico abrangente, envolvendo imagens, é importante na detecção de anomalias congênitas, como o PPDH.

Palavras-chave: felino; PPDH; defeito congênito; diagnóstico por imagem; necropsia.

\section{Introduction}

Peritoneopericardial diaphragmatic hernia (PPDH) is a rare condition that occurs in dogs and pericardium development (Harvey, 1983; Cunha, 2000; Banz and Gottfried, 2010). It is most cats and is caused by defective diaphragm and prevalent and accounts for $0.5 \%$ of all congenital 
heart diseases occurring in Weimaraner and Persian breeds (Liptak et al., 2002; Reimer et al., 2004; Banz and Gottfried, 2010). In PPDH, the organs and structures that can be found in the pericardial sac are the liver, spleen, small intestine, sickle cell ligament, omentum, and rarely the stomach (Evans and Biery, 1980; Schulman et al., 1985; Hay et al., 1989; Hunt and Johnson, 2003).

The cause of PPDH is not fully understood. The most commonly defended theory is that these hernias result from an altered embryonic development of the septum transversum, either through the appearance of a ventral diaphragmatic anomaly or through the formation of thin diaphragmatic tissues that rupture, resulting in anomalous communication between the peritoneal and pericardial cavities and allowing the passage of abdominal content into the pericardial sac (Banz and Gottfried, 2010; Park, 2010). Radiographic examination of the chest is indicative of PPDH, and notable findings include increased cardiac silhouette, dorsal tracheal displacement, overlapping of the diaphragmatic and caudal edges of the heart, and abnormal fat or gas densities in the cardiac silhouette (Ware, 2015).

This study describes the first report of congenital peritoneopericardial diaphragmatic hernia in a geriatric cat admitted to the veterinary hospital of the Federal University of Espírito Santo in Brazil.

\section{Description of the Case}

A 12-year-old male Persian cat was referred to the veterinary hospital. Clinical examination revealed hyporexia, cachexia, alopecia, dyspnea, post-bite lesions, a contaminated wound approximately $4 \mathrm{~cm}$ in size in the ventral region, and an irregularly shaped, adherent nodule in the left caudal breast.

Radiological examination revealed an anomalous globose-shaped cardiac silhouette, showing vestiges of the dorsal peritoneopericardial mesothelium and pulmonary caudal lobe retraction, which was suggestive of pleural effusion, reduced hepatic volume, and decreased cranial-abdominal circumference (Figure 1A). Radiographic findings suggested PPDH, possibly with liver lobe(s) as herniated content. For diagnostic confirmation, an ultrasonographic investigation was performed, confirming the presence of part of the liver adjacent to the heart.

Fine-needle aspiration cytology was performed on the abdominal nodulation, and the slides were stained using the Giemsa method. Cytopathological analysis revealed the presence of atypical epithelial cell groups suggestive of mammary carcinoma. Due to its overall corporal state, euthanasia was indicated. The corpse was sent to the necropsy.

During the necropsy, macroscopic examination of the corpse indicated a very poor nutritional state and focally extensive skin ulcers (Figure 1B). The nodule in the left caudal mamma had lobulations, an irregular surface, and ulceration (Figure 1C and 1D).

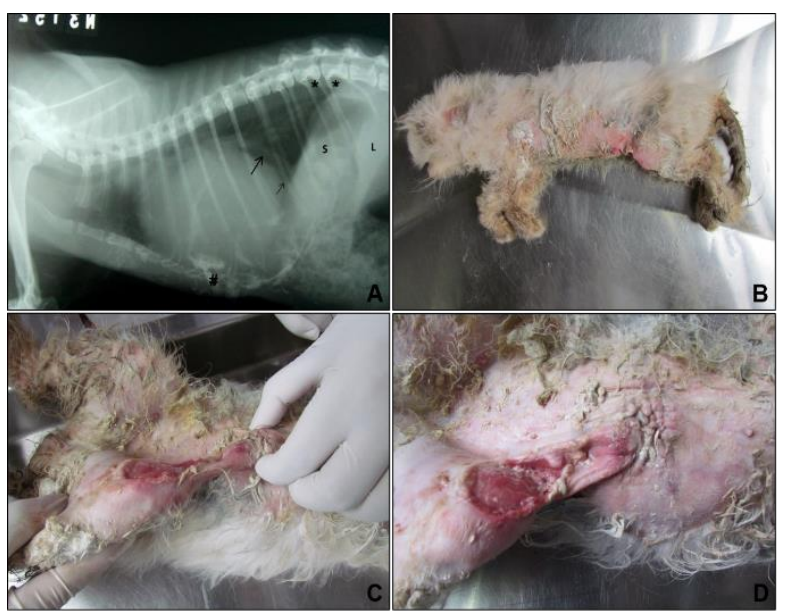

Figure 1. Congenital peritoneopericardial diaphragmatic hernia in a geriatric Persian cat. A) Radiography, lateral incidence: globose cardiac silhouette with dorsal peritoneal-pericardic mesothelium vestige (arrow). Pulmonary caudal lobes retraction is observed (*), suggestive of pleural efusion. Reduced hepatic silhouette (L) and stomach filled with gas (S) was observed. Some debris are seemed adhered to thoracic skin (\#). B) Macroscopic examination of the animal revealing very poor nutritional state and focally extensive skin ulcers. C) Nodule in the left caudal mamma with lobulations and an irregular surface in addition to ulceration. D) Layout of the anterior figure.

When the abdominal cavity was opened, a part of the liver was found inside the diaphragm (Figure 2A), and the thoracic view showed the heart and liver inside the pericardial sac (Figure 2B). We observed diaphragm communication with the pericardial sac (Figure 2C). The liver was congested. It was also observed that the left and right medial lobes, together with the accessory lobe, and the gallbladder were located inside the pericardium (Figure 2D). The right and left lateral lobes as well as caudate lobes were situated under the diaphragm, which showed a complete hernial sac approximately $5 \mathrm{~cm}$ in diameter. The heart was dilated and compressed, with caudocranial flattening, and the hepatic lobe was cranial to the 
heart (Figure 3A-D). There was also discrete lung edema, spleen rupture, and increased volume of the adrenal glands and kidneys.

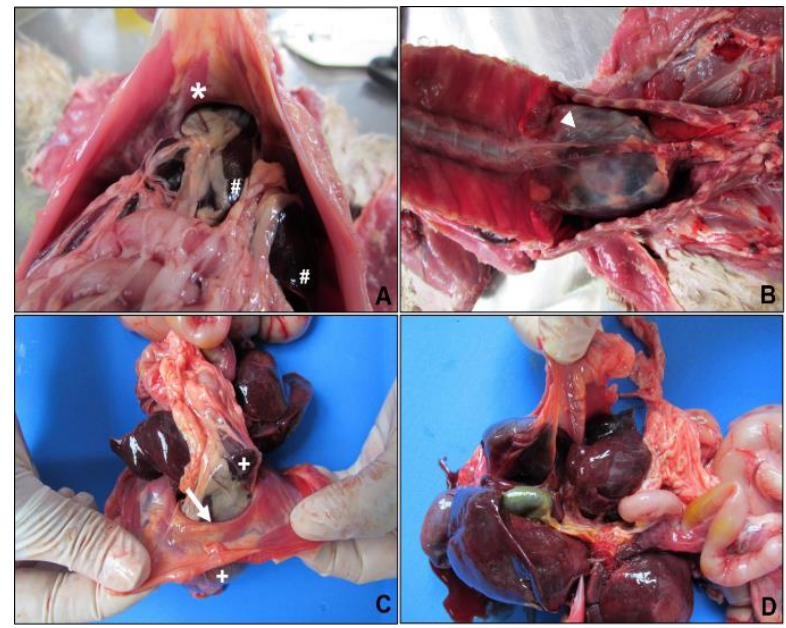

Figure 2. Necropsy of the Persian cat with PPDH. A) Opening of the abdominal cavity with part of the liver (\#) inside the diaphragm (*). B) Thoracic view with heart and liver inside pericardial sac (arrowhead). C) Diaphragm communication (arrow) with the pericardial sac (+). D) Liver deformed and congested.

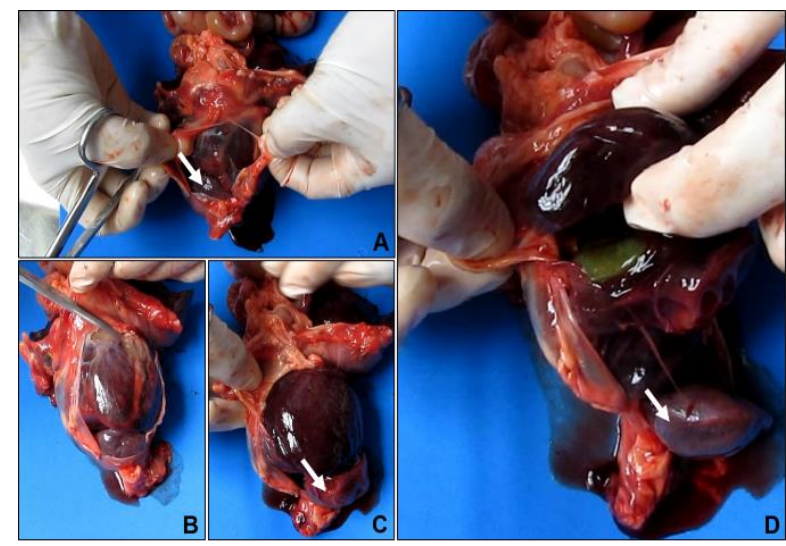

Figure 3. Necropsy of the Persian cat with PPDH. A) Opening of the pericardial sac showing the left medial lobe of the liver inside the sac. B) Layout of the anterior figure. C) Liver positioned cranially to heart with cardiac compression (arrow). D) Left and right medial lobes and accessory lobe beyond the gallbladder inside the pericardium with cardiac dilatation and compression (arrow).

At necropsy, the mammary and abdominal nodules were collected, fixed in $10 \%$ formalin, and sent for routine histopathological examination. Microscopic examination of the skin revealed epidermis with hyperkeratosis, lichenification, foci of ulceration, and diffuse mononuclear inflammatory infiltrate. In the superficial dermis, periglandular and perifollicular inflammatory infiltrates were observed. In the deep dermis and subcutaneous region, various granulomas were identified, with necrotic centers containing negative images of cylindrical and branched structures, surrounded by mononuclear inflammatory infiltrate and fibrous capsule. The abdominal region mass contained, besides granulomas, mammary carcinoma (Figure 4A). The material was stained with periodic acid Schiff. The presence of irregular fungal hyphae, segmented in the longitudinal and horizontal ways and typical of dermatophytic pseudomycetoma, was confirmed (Figure 4B-D).

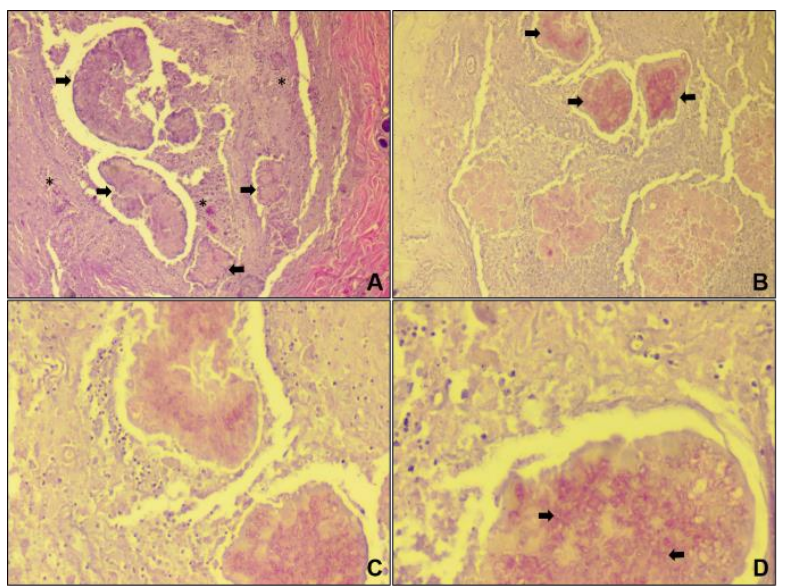

Figure 4. Microscopic examination of the skin of the Persian cat with PPDH. A) Diffuse mononuclear inflammatory infiltrate $(*)$ with multifocal granulomas (arrow) (HE staining; 4x magnification). B) Multifocal granulomas with necrotic centers containing negative images of cylindrical and branched structures (arrow), surrounded by mononuclear inflammatory infiltrate and fibrous capsule (PAS staining; 10x magnification). C) Layout of the anterior figure (PAS staining; 10x magnification); D) Images of cylindrical PAS positives septate hyphae (arrow) (PAS staining; 10x magnification).

\section{Discussion}

Peritoneopericardial diaphragmatic hernia is a rare birth defect, and its diagnosis is incidental. However, some animals may experience respiratory or gastrointestinal symptoms, which is more common in young animals, and the diagnosis may be confirmed in the first months of life (Liptak et al., 2002; Reimer et al., 2004; Banz and Gottfried, 2010; Park, 2010). In this study, the animal presented with dyspnea. Pulmonary metastasis was suspected, and PPDH was confirmed after a radiographic examination. PPDH is an anomaly that mainly affects long-haired cats, and the Persian breed is the most susceptible. Females are more affected than males (Reimer et al., 2004; Banz and Gottfried, 2010; Park, 2010), and our patient was male, which confirms the rarity. However, a family of Persian cats affected by PPDH and/or omphalocele has been reported, 
and the authors suggested that the cases were inherited and autosomal recessive (Margolis et al., 2018).

Radiographic examination outcomes can be suggestive of PPDH, with ultrasonography being the most indicated technique for diagnostic confirmation (Park, 2010), as performed in this case. However, Carbon et al. (2017) reported the diagnosis of PPDH using an echocardiogram that revealed the presence of a fluid-filled structure and part of the liver in the pericardial sac.

Treatment for PPDH has a favorable prognosis, and herniorrhaphy is generally successful with rare complications (Liptak et al., 2002; Reimer et al., 2004; Banz and Gottfried, 2010; Park, 2010). However, constrictive pericarditis has been reported in a female cat (4 years old, neutered, long hair) following PPDH correction surgery (Murphy et al., 2014). Our patient had other underlying diseases that complicated the hernia, and this informed the choice of euthanasia. It came from a rural area and belonged to tutors without the financial capacity to ensure adequate veterinary care. An echocardiogram was not performed for the same reason; it would not be authorized although it was indicated. With this challenge, necropsy was essential for diagnostic confirmation. A similar case has been described by Foster et al. (2011), which involved an alpaca with congenital PPDH confirmed on necropsy.

On external examination of the corpse, the skin lesions were typical of dermatophyte pseudomycetoma. According to Moraes et al. (2001), dermatophytes invade the deeper and nonkeratinized layers of the skin or even the hypodermis, in rare cases, and they can provoke an acute granulomatous inflammation of foreign body type. Dermatophyte pseudomycetoma was confirmed histologically. The findings were consistent with those observed by Tostes and Giuffrida (2003) and Pereira et al. (2006). The positive reaction of Splendori-Hoeppli, due to the compact filamentous structure of the hyphae and the absence of a cement matrix, permitted the classification of the lesion as a pseudomycetoma.

The pathogenesis of this deep mycotic infection has yet to be elucidated. Caretta et al. (1989) suggested that a symbiotic relationship between zoophilic dermatophytes and fleas may play a significant role in the spread of dermatophytosis and its sequelae. Moriello and DeBoer (1991) explained that dermatophyte infection may also be conditioned to changes in the host's bacterial and fungal saprophytic microbiota. Tuttle and Chandler (1983) believe that pseudomycetomas may appear as a sequel to preexisting skin lesions. Yager et al. (1986) credit part of the development of the pseudomycetoma to immunosuppression due to infectious processes or therapy. Thus, it is believed that the deep fungal dermatitis observed in the animal in this study was probably associated with immunosuppression and severe cachexia.

In our study, a mammary carcinoma was verified. This type of tumor is common in females; in males, the incidence varies from 1 to $5 \%$ (Lana et al., 2019). Thus, in males, it is rare, occurs slightly later, and generally affects those of an average age of 12 years, which are mixed breed and not neutered (Skorupski et al., 2005). Some authors have indicated that mammary carcinomas mainly affect breeds such as Domestic Short Hairs and Siamese (Misdorp, 2002; Rutteman and Kirpensteijn, 2003; Lana et al., 2019). In a study by Togni et al. (2013), $8 \%$ of the animals diagnosed with breast tumors were of the Persian breed; however, all were female. On the other hand, other studies point out that there is no race predisposition as the proportion between races is not known and the prevalence varies according to the region studied (Peleteiro, 1994). The tutors did not provide information about the use of progestogens or anything that would justify the neoplasm. They also did not notice the tumor previously and associated the lesions to bites by other cats.

At necropsy, the main finding was peritoneopericardial diaphragmatic hernia, in which much of the liver was inside the pericardial sac causing enormous heart compression. The liver was congested, and the heart was dilated. Mild pulmonary edema, which is a consequence of cardiac compression, was also observed.

\section{Conclusion}

This is the first report of PPDH, mammary carcinoma and pseudomycetoma, coexisting in a cat, which was admitted to the veterinary hospital of the Federal University of Espírito Santo in Brazil. Based on our findings, a complete clinical examination, involving imaging-assisted diagnosis, is useful in detecting congenital abnormalities such as peritoneopericardial diaphragmatic hernia, while histopathological analysis is important for diagnosing mammary carcinoma and pseudomycetoma. 


\section{Declaration of conflicting interests}

The authors declare that there is no conflict of interest. Authors alone are responsible for the content and writing of the article.

\section{Acknowledgments}

We would like to thank Editage (www.editage.com) for English language editing.

\section{References}

Banz, A.C.; Gottfried, S.D. Peritoneopericardial diaphragmatic hernia: a retrospective study of 31 cats and eight dogs. Journal of the American Animal Hospital Association, 46(6): 398-404, 2010.

Cabon, Q.; Carmel, E.N.; Cabassu, J. Cholecystopexy and Pericardial Pseudocyst Removal in a Dog with a Congenital Peritoneopericardial Diaphragmatic Hernia. Journal of the American Animal Hospital Association, 53(5): 270-276, 2017.

Caretta, G.; Mancianti, F.; Ajello, L. Dermatophytes and keratinophilic fungi in cats and dogs. Mycoses, 32(120): 620-626, 1989.

Cunha, O.; Pinto Filho, S.T.L.; Barbosa, G.S.; Raise, A.G.; Portella, L.C.V. Hérnia peritoneopericárdica em cão. Ciência Rural, 30(5): 899-902, 2000.

Evans, S.M.; Biery, D.N. Congenital peritoneopericardial diaphragmatic hernia in the dog and cat: a literature review and 17 additional case histories. Veterinary Radiology, 21(3): 108-116, 1980.

Foster, D.M.; Chinnadurai, S.K.; Nutt, J.N.; Pandiri, A.; Linder, K.E.; Alley, M.L., Smith, G.W. Congenital peritoneopericardial diaphragmatic hernia in an alpaca. Australian Veterinary Journal, 89(8): 51-54, 2011.

Harvey, H.J. Peritoneopericardial hernia. In: Bojrab, M.J. Current techniques in small animal surgery. $2^{\text {nd }}$ ed. Philadelphia: Lea \& Febiger, 1983. p.407-408.

Hay, W.H.; Woodfield, J.A.; Moon, M.A. Clinical, Echocardiographic, and Radiographic Findings of Peritoneopericardial Diaphragmatic Hernia in Two Dogs and a Cat. Journal of the American Veterinary Medical Association, 195(9): 1245-1249, 1989.

Hunt, G.B.; Johnson, K.A. Diaphragmatic, Pericardial, and Hiatal Hernia. In: Slatter, D.
Textbook of small animal surgery. $3^{\text {rd }}$ ed. Philadelphia: Elsevier Science. 2003. p. 471487.

Lana, S.E.; Rutteman, G.R.; Withrow, S.J. Tumors of the mammary gland. In: Vail, D.M.; Thamm, D.H.; Liptak, J.M. Withrow \& MacEwen's small animal clinical oncology. $6^{\text {th }}$ ed. St. Louis: Saunders Elsevier, 2019. p.619-636.

Liptak, J.M.; Bissett, S.A.; Allan, G.S.; Zaki, S.; Malik, R. Hepatic cysts incarcerated in a peritoneopericardial diaphragmatic hernia. Journal of Feline Medicine \& Surgery, 4(2): 123-125, 2002.

Margolis, C.; Pipan, M.Z.; Demchur, J.; Or, M.; Henthorn, P.; Casal, M.L. Congenital peritoneopericardial diaphragmatic hernia in a family of Persian cats. Journal of Feline Medicine and Surgery Open Reports, 4(2): 2055116918804305, 2018.

Misdorp, W. Tumors of the mammary gland. In: Meuten, D.J. Tumors in domestic animals. $4^{\text {th }}$ ed. Iowa: Blackwell Publishing, 2002. p.575-606.

Moraes, M.A.P.; Machado, A.A.L.; Medeiros Filho, P.; Reis, C.M.S. Pseudomicetoma dermatofítico: relato de um caso devido a Trichophyton tonsurans. Revista da Sociedade Brasileira de Medicina Tropical, 34(3): 291-294, 2001.

Moriello, K.A.; DeBoer, D.J. Fungal flora of the haircoat of cats with and without dermatophytosis. Journal of Medical and Veterinary Mycology, 29(5): 285-292, 1991.

Murphy, L.A.; Russel, N.J.; Dulake, M.I.; Nakamura, R.K. Constrictive pericarditis following surgical repair of a peritoneopericardial diaphragmatic hernia in a cat. Journal of Feline Medicine \& Surgery, 16: 708-712, 2014.

Park, R.D. O diafragma. In: Thrall, D.E. Diagnóstico de radiologia veterinária. Rio de Janeiro: Elsevier, 2010. p.525-540.

Peleteiro, M.C. Tumores mamários na cadela e na gata. Revista Portuguesa de Ciências Veterinárias, 89(509): 10-28, 1994.

Pereira, A.N.; Damico, C.B.; Souza, H.J.M.; Corgozinho, K.B.; Graça, R.; Almelda, E.C.P.; Ferreira, A.M.R. Pseudomicetoma Dermatofítico causado por Microsporum canis em gato da raça Persa. Acta Scientiae Veterinariae, 34(2): 193-196, 2006. 
Reimer, S.B.; Kyles, A.E.; Filipowicz, D.E.; Gregor, C.R. Long-term outcome of cats treated conservatively or surgically for peritoneopericardial diaphragmatic hernia: 66 cases (1987-2002). Journal of the American Veterinary Medical Association, 224(5): 728-732, 2004.

Rutteman, G.R.; Kirpensteijn, J. Tumours of the mammary glands. In: Dobson, J.M.; Lascelles, B.D.X. BSAVA Manual of Canine and Feline Oncology. Gloucester: British Small Animal Veterinary Association, 2003. p.234242.

Schulman, A.J.; Lusk, R.; Lippincott, C.L.; Ettinger, S.J. Congenital peritoneopericardial diaphragmatic hernia in a dog. Journal of the American Animal Hospital Association, 21: 655-662, 1985.

Skorupski, K.A.; Overley, B.; Shofer, F.S.; Goldschmidt, M.H.; Miller, C.A.; Sorenmo, K.U. Clinical characteristics of mammary carcinoma in male cats. Journal of
Veterinary Internal Medicine, 19(1): 52-55, 2005.

Togni, M.; Masada, E.D.; Kommers, G.D.; Fighera, R.A.; Irigoyen, L.F. Estudo retrospectivo de 207 casos de tumores mamários em gatas. Pesquisa Veterinária Brasileira, 33(3): 353-358, 2013.

Tostes, R.A.; Giuffrida, R. Pseudomicetoma dermatofítico em felinos - Relato de caso. Ciência Rural, 33(2): 363-365, 2003.

Tuttle, P.A.; Chandler, F.W. Deep dermatophytosis in a cat. Journal of the American Veterinary Medical Association, 183(10): 1106-1108, 1983.

Ware, W.A. Pericardial Disease. In: Abbott, J.A. Small animal cardiology secrets. Amsterdam: Hanley \& Belfus, 2000. p.272275.

Yager, J.A.; Wilcock, B.P.; Lynch, J.A.; Thompson, A.R. Mycetoma-like granuloma in a cat caused by Microsporum canis. Journal of Comparative Pathology, 96(2): 171-176, 1986. 